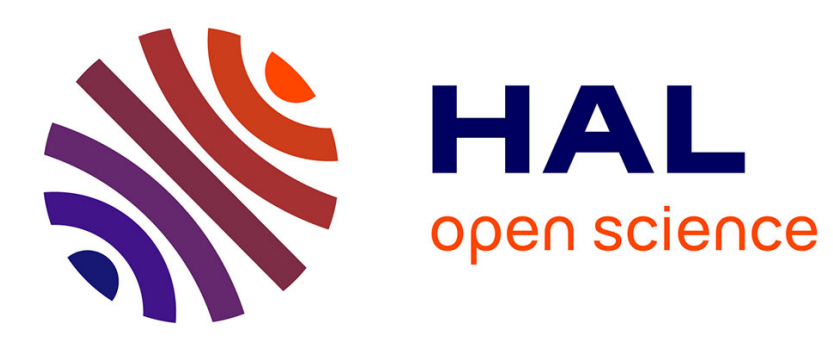

\title{
Is there a risk-dilution effect of naturally fallen fruits on post-dispersal seed predation by wood mice?
}

Kazuaki Takahashi, Tomohiko Kamitani

\section{To cite this version:}

Kazuaki Takahashi, Tomohiko Kamitani. Is there a risk-dilution effect of naturally fallen fruits on post-dispersal seed predation by wood mice?. Annals of Forest Science, 2013, 70 (4), pp.381-390. $10.1007 / \mathrm{s} 13595-013-0267-y$. hal-01201481

\section{HAL Id: hal-01201481 \\ https://hal.science/hal-01201481}

Submitted on 17 Sep 2015

HAL is a multi-disciplinary open access archive for the deposit and dissemination of scientific research documents, whether they are published or not. The documents may come from teaching and research institutions in France or abroad, or from public or private research centers.
L'archive ouverte pluridisciplinaire HAL, est destinée au dépôt et à la diffusion de documents scientifiques de niveau recherche, publiés ou non, émanant des établissements d'enseignement et de recherche français ou étrangers, des laboratoires publics ou privés. 


\title{
Is there a risk-dilution effect of naturally fallen fruits on post-dispersal seed predation by wood mice?
}

\author{
Kazuaki Takahashi • Tomohiko Kamitani
}

Received: 13 March 2012 / Accepted: 23 January 2013 /Published online: 15 February 2013

(C) INRA and Springer-Verlag France 2013

\begin{abstract}
- Aims The aim of this study was to test the hypothesis that heavy predation of fallen fruits reduces the predation of neighboring post-dispersed seeds.

- Methods We performed a seed/fruit removal cafeteria experiment to assess the effects of seed species, of fruit species, and of density of fallen fruits on seed predation by wood mice (Apodemus sp.). In total, 6,930 seeds and 9,660 fruits from seven species were used. A generalized linear mixed model procedure was used to test these effects.

- Results Seed predation was significantly affected by the species of both seeds and neighboring fruits, but not by their density. Multiple comparison tests showed that most of treatments tested had no significant effects of species and density of neighboring fruits on seed removal. However, seed removal was significantly lower in some treatments with fruits than in the treatments without fruits for one of the seven seed species tested. Seed removal of two species tested was significantly differed among some treatments with different fruit species.

- Conclusion Most of the results in this study do not support our overall hypothesis. However, a part of results supported our hypothesis, suggesting that seed removal is affected by complex interactions between the preference of wood mice for fruits and fruiting environment.
\end{abstract}

Handling Editor: Bruno Fady

Contribution of the co-authors Kazuaki Takahashi and Tomohiko

Kamitani: designing the experiment and writing the paper.

K. Takahashi $(\bowtie)$

Faculty of Tourism and Environmental Studies, Nagano

University, 658-1 Shimonogo,

Ueda, Nagano 386-1298, Japan

e-mail: k-takahashi@nagano.ac.jp

T. Kamitani

Faculty of Agriculture, Niigata University, 2-8050 Ikarashi,

Niigata 950-2181, Japan
Keywords Apodemus spp. · Bird-dispersed seed rain · Fruiting plant $\cdot$ Perch $\cdot$ Seed/fruit-removal experiment . Wood mouse · Fallen fruit · Pinus thunbergii stand . Seed predation

\section{Introduction}

Spatial patterns of fleshy-fruited plant recruitment depend on seed rain, but are also affected by post-dispersal processes such as seed predation, germination, and mortality (Alcántara et al. 2000; Holl 2002). Therefore, a key question is whether patterns of plant recruitment are concordant with those of seed rain (Schupp 1995). Frugivorous birds are important seed dispersers of fleshy-fruited plants. These birds deliver more of their seeds under perches (McClanahan and Wolfe 1987; Holl 2002) or plants bearing attractive fleshy fruits (Slocum and Horvitz 2000; Takahashi and Kamitani 2004) than in open sites or clearings (Izhaki et al. 1991; Herrera et al. 1994). Intensive bird-dispersed seed rain beneath fruiting plants can cause spatial heterogeneous plant recruitment in early successional plant communities (Robinson and Handel 1993; Toh et al. 1999). Thus, fruits of fleshy-fruited plants facilitate plant colonization, thereby influencing the spatial distribution and population dynamics of plants as well as plant succession (Robinson and Handel 1993; Schupp 1995; Holl 2002).

Recruitment models have predicted that fruit-bearing plants are often focal sites for seed predators (Janzen 1970; Connell 1971; Nathan and Casagrandi 2004). Subsequent empirical studies have indicated that bird-dispersed seeds and seeds within fruits fallen naturally beneath fruiting plants suffer heavy predation by rodents including wood mice (Apodemus spp.; Wilson and Whelan 1990; Masaki et al. 1994), and the level of predation pressure depends on seed density (Wilson and Whelan 1990; cf., Alcántara et al. 2000). Thus, wood mouse seed predation can potentially influence plant colonization (Wilson and Whelan 1990; Kollmann et al. 
1998), and understanding post-dispersal seed/fruit predation beneath fruiting plants is necessary to understanding seed predation and subsequent colonization patterns and processes in different plant species in various microhabitats (Russell and Schupp 1998).

In temperate Japan, two species of wood mice, Apodemus speciosus and Apodemus argenteus, which act as the major agents of secondary dispersal of acorns and nuts in the family Fagaceae, are also principal seed predators (Kikuzawa 1988; Miguchi 1996; Takahashi et al. 2007). Therefore, the two species are thought to be main seed dispersers/predators of fleshy-fruited plants, and also it is believed that many fleshyfruited plants suffer heavy post-dispersal seed predation by the two species. However, little data exist on the potential of wood mice to disperse and predate small-sized bird-dispersed seeds in Japan. Generally, wood mouse foraging activity is influenced by density, size, and nutrition of seeds/fruits on the ground (Wilson and Whelan 1990; Kollmann et al. 1998; Den Ouden et al. 2005). In addition, the density and type of litter (Price and Jenkins 1986; Schupp 1988), vegetation cover (Herrera et al. 1994), and distance of seeds/fruits from a mother plant (Howe et al. 1985; Notman et al. 1996) affect wood mouse foraging. Therefore, wood mouse post-dispersal seed predation beneath fruiting plants would be affected by those factors and thus would change the distribution both of seeds from bird-dispersed seed rain and of fruits that dropped naturally under a mother plant. However, there is little information regarding wood mouse post-dispersal seed/fruit predation when bird-dispersed seeds and fruits co-occur beneath fruiting plants. Understanding of these events by predation behavior of wood mice would help to understand the pattern of fleshy-fruited plant recruitment near fruiting plants.

The predator satiation hypothesis predicts that low levels of seed predation are caused by high seed input under fruiting plants (Janzen 1971; Burkey 1994). In this study, we predicted that wood mice would disregard bird-dispersed seeds if they prefer fruits to seeds and/or are confused by the presence of many fruits. Under such conditions, predation pressure on bird-dispersed seeds would be reduced, and seeds dispersed around fallen fruits may escape predation. Thus, our overall hypothesis was that high density of fallen fruits satiates wood mice as a fruit/seed eater and thus that wood mice consumption of fallen fruits under conditions of high fallen fruit density would reduce the predation of neighboring post-dispersal seeds. Evaluation of this hypothesis is necessary to better understand the distribution of seeds after wood mouse predation of bird-dispersed seeds and the subsequent seed bank formation in various microhabitats.

Our objective was to investigate how preferences of wood mice for bird-dispersed seeds of various plant species depend on fallen fruit conditions in a microhabitat beneath a fruiting plant. We used a seed/fruit cafeteria removal experiment to determine the effects of fallen fruits on removal of bird-dispersed seeds beneath different fruiting plant species. The experiment reproduced bird-dispersed seed rain and fruits that had naturally fallen from a parent plant. Specifically, we asked whether the presence or absence, density, and/or species of fallen fruit affected the removal of bird-dispersed seeds beneath the fruiting plant, and if so, whether removal of fallen fruits was related to removal of neighboring dispersed seeds.

\section{Material and methods}

\subsection{Study site}

The study was conducted in a 1 -ha $(100 \times 100-\mathrm{m})$ plot located in a 56-year-old Pinus thunbergii Parl. stand, which is the most common species of pine planted as a windbreak in Japan, on a coastal sand dune near Mt. Kakuda, Niigata Prefecture, central Japan $\left(37^{\circ} 47^{\prime} \mathrm{N}, 138^{\circ} 49^{\prime} \mathrm{E}\right)$. Being artificial, these pine stands develop on coastal sand dunes that lack a forest seed bank and forest pioneer species; thus, we considered such a pine stand to be a suitable location to evaluate patterns of colonization and spatial distribution of plants in early successional plant communities. Annual mean temperature and rainfall for 3 years containing the study year in the area are $14.4{ }^{\circ} \mathrm{C}$ and $1,964 \mathrm{~mm}$, respectively. The main canopy tree species in the plot was $P$. thunbergii $[$ height $=16.1 \pm 3.5 \mathrm{~m}($ mean $\pm \mathrm{SD})$; density $=960$ treesha ${ }^{-1}$ ], and the sub-canopy consisted of other woody species such as Prunus verecunda (Koidz.) Koehne, Quercus serrata Murray (1988), and Albizia julibrissin Durazz. (height $=5.9 \pm 1.4 \mathrm{~m}$; density $=580$ treesha $^{-1}$ ).

In autumn 2001 when our study was performed, 12 species that bear fleshy fruits in autumn were present in the study plot: six shrubs (Viburnum dilatatum Thunb., Callicarpa japonica Thunb., Rhus trichocarpa Miq., Neolitsea sericea (Blume) Koidz., Euonymus alatus (Thunb.) Siebold f. stiatus (Thunb.) Makino, and Euonymus sieboldianus Blume) and six vines (Cocculus trilobus (Thunb.) DC., Paederia scandens (Lour.) Merr., Smilax china L., Lonicera japonica Thunb., Akebia quinata (Houtt.) Decne., and Vitis thunbergii Siebold et Zucc.), in order of descending numbers of individuals. The study year was a good mast year for these plant species. Most fruits were picked and dispersed from mid-October to early December by several fruit-eating birds such as the browneared bulbul (Hypsipetes amaurotis Temminck), the dusky thrush (Turdus naumanni Temminck), the pale thrush (Turdus pallidus Gmelin), and the Japanese white-eye (Zosterops japonicus Temminck \& Schlegel). These species represent the primary seed dispersers in Japan (Kominami 1987; Noma and Yumoto 1997). Due to this fruit dispersal and naturally falling fruits, plants in the study plot bore few ripe fleshy fruits at the beginning of the study. 


\subsection{Seed/fruit removal cafeteria experiment}

The seed/fruit removal experiment ran from 13 December 2001 to 28 April 2002. The experiment included 330 baskets assembled from $0.86-\mathrm{mm}$ mesh polyester cloth and 5$\mathrm{cm}$ mesh wire netting (Fig. 1). Forty-five plants each of seven autumn-fruiting plant species [four shrubs (C. japon$i c a, N$. sericea, $R$. trichocarpa, and $V$. dilatatum) and three vines (C. trilobus, P. scandens, and S. china)] and 15 plants of a summer-fruiting shrub species (Morus bombycis Koidz.) were randomly selected for the experiment $(n=330$ plants). Summer-fruiting $M$. bombycis shrubs, which supply no fallen fruits on the forest floor in autumn, were selected as control plants. All selected plants were located under canopy trees, and their heights ranged from 1.5 to $3.0 \mathrm{~m}$. The host tree of all selected vines was early-summer-fruiting $P$. verecunda, which bears no fruit in autumn.

Ripe fruits and seeds of the seven autumn-fruiting species (Table 1) were randomly collected from plants in the study plot at the beginning of December 2001. To provide seeds for the experiment, we peeled the pulp from about half of the collected fruits. Seeds without pulp were soaked in water to remove the floating empty and insect-damaged seeds. These seeds and fruits were conserved in the laboratory, under temperatures similar to those experienced by seeds and fruits staying on the ground in the field, until they were relocated to the experimental plot.

The baskets for the seed/fruit cafeteria experiment consisted of pairs of large $(30 \times 30 \times 3 \mathrm{~cm})$ and small $(10 \times 10 \times$ $1 \mathrm{~cm}$ ) baskets. Large baskets were buried in the ground to a depth of $3 \mathrm{~cm}$ and nailed in place. A small basket was placed at the center of each large basket. One set of baskets was positioned beneath each of the 330 selected plants. Fruits and seeds were placed inside large and small baskets, respectively, so that when wood mice entered the baskets, they would first see fruits and could then approach seeds.

The experimental design reproduced real patterns of birddispersed seeds and naturally fallen fruits. To determine the numbers of seeds and fruits to put in the baskets, we estimated means, maximums, and minimums of densities of bird-dispersed seeds and naturally fallen fruits per basket (Table 1) using data from $1.5-\mathrm{m}^{2}$ rectangular traps placed beneath fruiting plants of the seven species $(n=10 \times 7$ species) at the same study site between 20 October 1999 and 7 January 2000 (Takahashi and Kamitani 2003, 2004), which was a good mast year for these plant species. Because the composition of bird-dispersed seeds beneath plants was not affected by the species of plant on which birds defecated or regurgitated and was thus similar among plant species (Takahashi and Kamitani 2003), 21 seeds of the seven autumn-fruiting plant species (three seeds per plant species) were placed in each small basket $(n=330)$. For the treatments with fruits, fruits of the same species as the fruiting plant overhead were placed in each large basket (around the small basket). Because densities of fallen fruits varied remarkably with individuals and species of fruiting plants, we used three different fruit densities: seven, 21 , and 63 fruits per basket, with 105 baskets per treatment $(n=105 \times 3)$. Moreover, to approximate actual situations in which few fruits fell to the forest floor in winter, we did not replace removed fruits with new fruits. Thus, fruit densities in the baskets were not kept constant during the experiment. For the treatments
Fig. 1 A set of baskets containing seeds and fruits

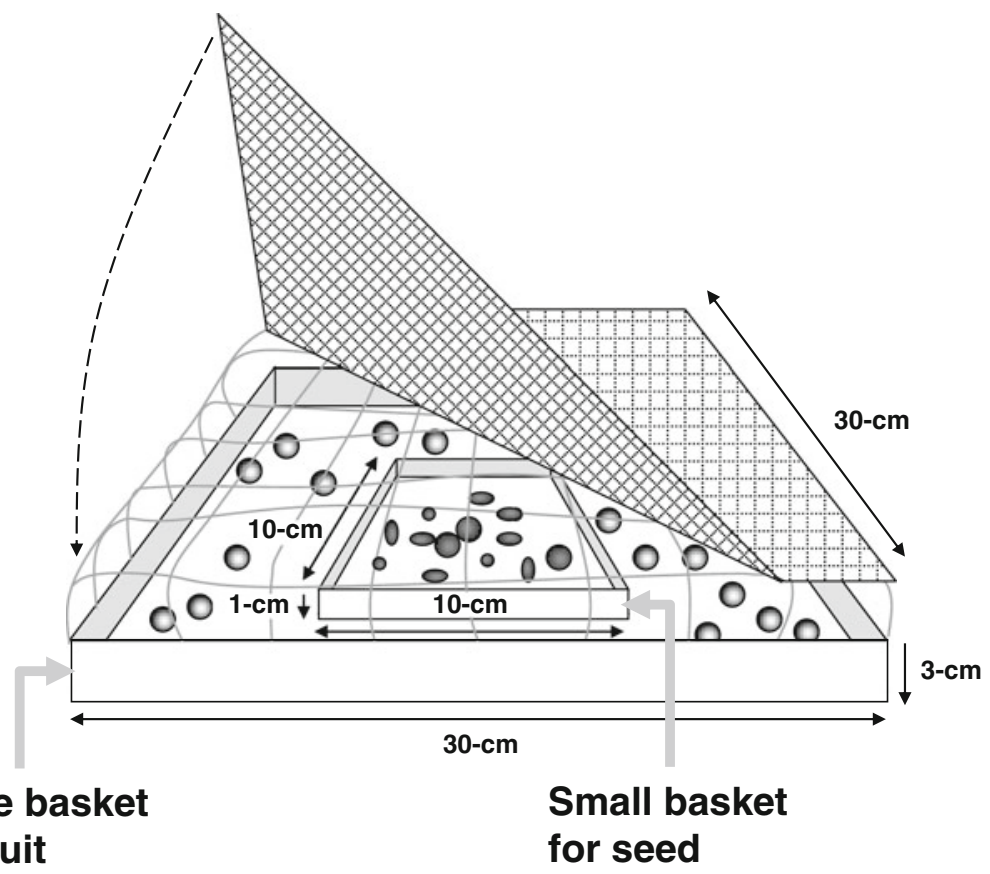

\begin{abstract}
Small basket for seed
\end{abstract}

\section{Large basket for fruit}


Table 1 Fruit size, seed size, and mode number of seeds per fruit (mean $\pm \mathrm{SD}, n=20$ fruits or seeds) and estimated densities of bird dispersed seeds and naturally fallen fruits per basket based on data collected in $1.5-\mathrm{m}^{2}$ rectangular traps placed beneath the seven study plant species $(n=10 \times 7$ species) between 20 October 1999 and 7 January 2000

\begin{tabular}{|c|c|c|c|c|c|c|c|c|c|c|c|}
\hline \multirow[t]{2}{*}{ Plant species } & \multirow[t]{2}{*}{$\begin{array}{l}\text { Fruit size } \\
(\mathrm{mm})\end{array}$} & \multirow[t]{2}{*}{$\begin{array}{l}\text { Seed size } \\
(\mathrm{mm})\end{array}$} & \multirow[t]{2}{*}{$\begin{array}{l}\text { Mode number of seeds } \\
\text { per fruit }\end{array}$} & \multicolumn{4}{|c|}{$\begin{array}{l}\text { Bird-dispersed seeds (no. } \\
0.09 \mathrm{~m}^{-2} \text { ) }\end{array}$} & \multicolumn{4}{|c|}{ Fallen fruits (no. $0.09 \mathrm{~m}^{-2}$ ) } \\
\hline & & & & Mean & SD & Max & Min & Mean & SD & $\operatorname{Max}$ & Min \\
\hline Callicarpa japonica & $4.60 \pm 0.49$ & $1.61 \pm 0.13$ & 4 & 33.9 & 27.4 & 93.2 & 9.1 & 99.2 & 64.4 & 200.4 & 25.2 \\
\hline Cocculus trilobus & $6.93 \pm 0.42$ & $4.69 \pm 0.18$ & 1 & 4.7 & 7.7 & 26.4 & 0.8 & 3.1 & 3.9 & 12.7 & 0.1 \\
\hline Neolitsea sericea & $10.89 \pm 0.39$ & $8.48 \pm 0.29$ & 1 & 7.1 & 8.2 & 27.9 & 1.4 & 0.3 & 0.2 & 0.5 & 0.0 \\
\hline Paederia scandens & $5.74 \pm 0.29$ & $3.72 \pm 0.14$ & 2 & 3.6 & 5.1 & 16.6 & 0.3 & 0.5 & 0.5 & 1.3 & 0.0 \\
\hline Rhus trichocarpa & $4.09 \pm 0.14$ & $3.31 \pm 0.14$ & 1 & 0.8 & 0.6 & 2.0 & 0.1 & 8.8 & 6.9 & 24.5 & 1.8 \\
\hline Smilax china & $8.29 \pm 0.31$ & $4.53 \pm 0.34$ & 3 & 1.3 & 1.1 & 3.1 & 0.0 & 2.5 & 4.4 & 14.4 & 0.0 \\
\hline Viburnum dilatatum & $6.39 \pm 0.27$ & $4.73 \pm 0.18$ & 1 & 4.3 & 4.7 & 15.7 & 0.2 & 12.2 & 6.2 & 22.8 & 4.9 \\
\hline Mean of 7 species & & & & 8.0 & 7.8 & 26.4 & 1.7 & 18.1 & 12.4 & 39.5 & 4.6 \\
\hline
\end{tabular}

without fruits, no fruit was placed in the control baskets ( $n=$ 15 ) beneath $M$. bombycis shrubs. In total, 6,930 seeds with full kernels and 9,660 fruits were used in the experiment.

Although two species of wood mice, A. speciosus Temminck and $A$. argenteus Temminck, are the principal post-dispersal seed predators in Japan (Kikuzawa 1988; Miguchi 1996), various animals such as medium-sized mammals (e.g., foxes, badgers, raccoon dogs, and martens), birds, and ants feed on seeds and fruits of fleshy-fruited plants (e.g., Higuchi 1977; Hayashida 1989; Koike et al. 2008). To separate the impact of foraging by wood mice from that of foraging by other animals, the upper part of each basket was fully enclosed with 5-cm-mesh wire netting to allow wood mice to enter. Ants were not found during the experiment and were thus not considered to be frequent seed predators during the winter. Each basket was covered with 0.86-mm-mesh polyester cloth to exclude bird-dispersed seed rain and fruits, seeds, or leaves shed from overhanging plants (Fig. 1).

\subsection{Wood mice trapping}

We conducted a mark-recapture study of wood mice populations using 100 Sherman live traps $(30 \times 9 \times 7 \mathrm{~cm})$ baited with sunflower seeds and sweet potatoes. Each trap was covered with a plastic bag to exclude rainfall, and cotton bedding was provided to prevent hypothermia. The study plot was divided into a grid of 100 cells $(10 \times 10 \mathrm{~m})$, and one trap was placed at the center of each grid cell. Live trapping was conducted immediately after the end of the experiment for five consecutive nights (28 April to 3 May 2002). Traps were checked daily at dawn. The density of wood mice was assessed using the mark-recapture data using Petersen's method (Seber 1982). We came to the conclusion that about 24 and eight individuals of $A$. speciosus and $A$. argenteus, respectively, were present per hectare.

\subsection{Data analyses}

Generalized linear mixed models (GLMMs) with the binomial family and logit link were used to determine the effects of species identity of seeds, fruit-species identity, and density of neighboring fruits on the numbers of removed seeds per species in each of all baskets. Density of neighboring fruits was treated as a covariate factor in GLMMs. To determine the best predictive GLMM, models having the lowest Akaike's information criterion (AIC) were selected. Differences in numbers of removed seeds per species among fruit-species and fruit-density treatments were examined with Tukey's honestly significant difference (HSD) tests. Differences in numbers of fruits removed among fruitspecies treatments were also tested with Tukey's HSD tests. To assess whether the numbers of neighboring fruits removed affected the numbers of seeds removed across the seven fruit-species treatments of different fruit density, simple regression analyses were performed using averages from within-species fruit treatments in each fruit-density treatment. To assess the effects of species of neighboring fruit on the preference of wood mice for seeds of the seven species, intraspecific correlations of species rank order of the number of removed seeds per species were tested with Spearman's rank correlation. A significant positive correlation coefficient would suggest that the quantitative composition of seeds removed is similar between two-fruit species treatments. All analyses were carried out using R 2.14.0 (R Development Core Team 2011).

\section{Results}

GLMM results showed that seed removal per species was significantly affected by fruit-species identity of neighboring 
fruits as well as species identity of seeds, but not by density of neighboring fruits (Table 2). Multiple comparison tests on seed removal showed that most of total 148 treatments tested had no significant effects of species and density of neighboring fruits on seed removal (Fig. 2). However, there are significant effects of the presence or absence of neighboring fruits on seed removal in two (C. trilobus and $V$. dilatatum) of seven fruit-species treatments. Fewer seeds of $S$. china were removed from baskets in treatments with 63 fruits than in treatments without fruits (Tukey's HSD tests, $P<0.05$; Fig. 2). Multiple comparison tests also indicated significant effects of neighboring fruit species on seed removal of $P$. scandens, and $R$. trichocarpa in C. trilobus, N. sericea, and/or $R$. trichocarpa fruit treatments (Tukey's HSD tests, $P<0.05$; Fig. 2). For example, the number of seeds of $P$. scandens was significantly smaller in $R$. trichocarpa fruit treatments with seven fruits than $C$. trilobus and $N$. sericea fruit treatments with 21 fruits (Fig. 2). For R. trichocarpa seeds, the numbers of seeds removed were significantly smaller in $R$. trichocarpa fruit treatments with seven fruits than $C$. trilobus fruit treatments with 21 fruits (Fig. 2).

Multiple comparison tests on fruit removal showed that there were significant effects of fruit-species identity of neighboring fruits on fruit removal in each fruit-density treatment (Tukey's HSD tests, $P<0.05$; Fig. 3). For all of three fruit-density treatments, the numbers of $C$. japonica, $C$. trilobus, and $V$. dilatatum fruits removed around the seeds were significantly larger than those of $N$. sericea, P. scandens, R. trichocarpa, and S. china fruits (Fig. 3). Wood mice preferred $N$. sericea (the total number of fruits removed; 220), S. china (351), P. scandens (399), R. trichocarpa
(434), C. japonica (829), V. dilatatum (1311), and C. trilobus fruits $(1,326)$, in that order.

Regressions indicated that the mean number of seeds removed were significantly and negatively correlated with the mean number of neighboring fruits removed across the seven fruit species treatments for in $N$. sericea seeds in the treatments with 21 fruits and N. sericea, R. trichocarpa, and $S$. china seeds in the treatments with 63 fruits (Pearson's correlation test, $P<0.05$; Table 3 ). For most of the treatments with seven and 21 fruits, there was no significant correlation between seed removal and neighboring fruit removal (Pearson's correlation test, $P \geq 0.05$; Table 3).

Significant positive correlations of species rank order were found in the numbers of removed seeds of the same species between different fruit species treatments in many pairs (treatments with seven fruits, 21 pairs; treatments with 21 fruits, 22 pairs; treatments with 63 fruits, 23 pairs) of all combinations (28 pairs), and the quantitative compositions of seeds removed were similar among the seven fruit species treatments (Spearman's rank correlation test, $P<0.05$; Table 4). Wood mice preferred $C$. trilobus (the total number of seeds removed; 18), V. dilatatum (64), N. sericea (140), P. scandens (290), C. japonica (353), S. china (459), and R. trichocarpa seeds (472), in that order. There was no significant correlation between wood mice preference for seeds and that for fruits (Pearson's correlation test, $r=-0.65, P \geq 0.05$ ).

\section{Discussion}

Because $A$. speciosus and $A$. argenteus were found in study area, we concluded that these two species of wood mouse
Table 2 Best-fit model for generalized linear mixed models after model selection on the effects of species identity of seeds, fruitspecies identity, and density of neighboring fruits on the numbers of removed seeds per species in each of all baskets

\begin{tabular}{|c|c|c|c|c|}
\hline Model & AIC & \multicolumn{2}{|c|}{ Explanatory variable } & Coefficients \\
\hline Null & 4,108 & \multicolumn{2}{|l|}{ (Intercept) } & $2.792 * * *$ \\
\hline \multirow[t]{15}{*}{ Seed species + fruit species + fruit density } & 3,405 & (Intercept) & & $0.461 \mathrm{~ns}$ \\
\hline & & \multirow[t]{6}{*}{ Seed species } & Cocculus trilobus & $6.210 * * *$ \\
\hline & & & Neolitsea sericea & $2.644 * * *$ \\
\hline & & & Paederia scandens & $0.747 * *$ \\
\hline & & & Rhus trichocarpa & $-0.764 * *$ \\
\hline & & & Smilax china & $-0.868 * *$ \\
\hline & & & Viburnum dilatatum & $4.172 * * *$ \\
\hline & & \multirow[t]{7}{*}{ Fruit species } & Cocculus trilobus & $0.725^{*}$ \\
\hline & & & Neolitsea sericea & $1.808 * * *$ \\
\hline & & & Paederia scandens & $1.016^{* *}$ \\
\hline & & & Rhus trichocarpa & $0.148 \mathrm{~ns}$ \\
\hline & & & Smilax china & $0.828 * *$ \\
\hline & & & Viburnum dilatatum & $0.054 \mathrm{~ns}$ \\
\hline & & & Non-fruit & $2.749 * * *$ \\
\hline & & \multicolumn{2}{|l|}{ Fruit density } & $-0.004 \mathrm{~ns}$ \\
\hline
\end{tabular}

$* P<0.05 ; * * P<0.01 ; * * * P<$ 0.001 , ns $P \geq 0.05$ (significance levels) 
Callicarpa japonica

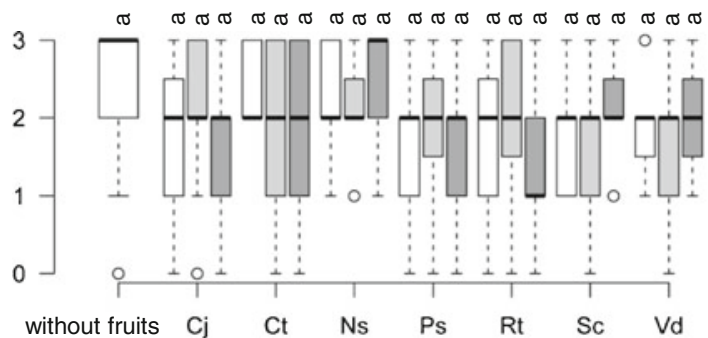

Neolitsea sericea

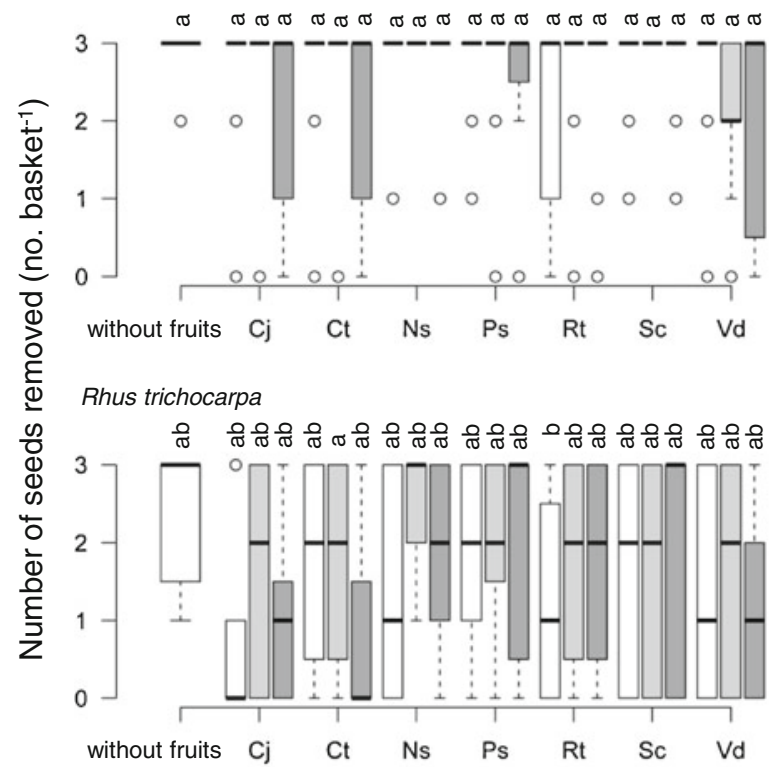

Viburnum dilatatum

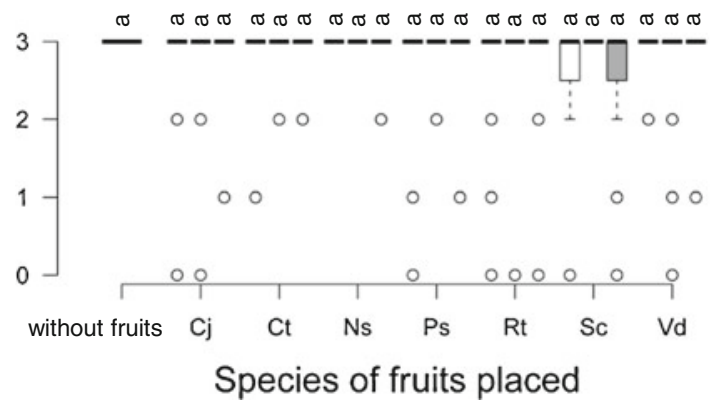

Cocculus trilobus

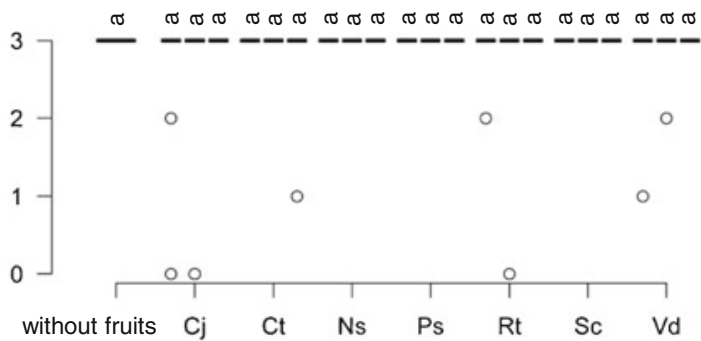

Paederia scandens

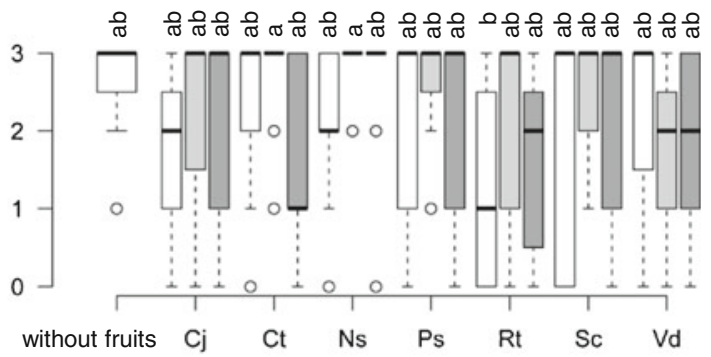

Smilax china

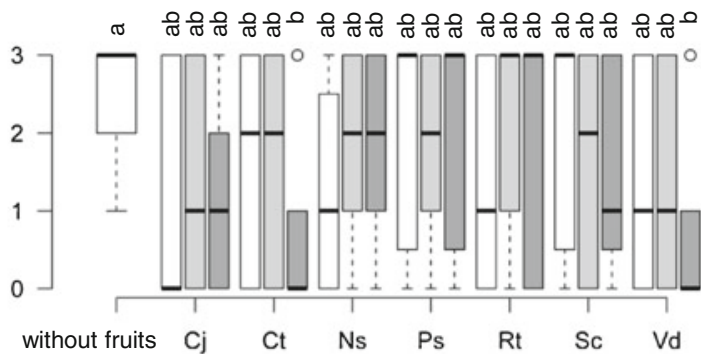

Treatments with 7 Fruits

Treatments with 21 Fruits

Treatments with 63 Fruits

\section{Species of fruits placed}

Fig. 2 The numbers of seeds removed in the treatments with fruits $[n=$ 21 baskets per treatment ( 7 fruit species $\times 3$ fruit density)] and treatments without fruits ( $n=15$ baskets). Different letters show significant differences among 22 fruit treatments $(P<0.05$, Tukey's HSD test). Each box represents an interquartile range, and the vertical line inside the box indicates the median. The whiskers extend to the lowest and

acted as agents of seed and fruit removal in our experiment. Our seed/fruit removal experiment revealed that density of neighboring fruits had no significant effects on seed removal for six of the seven seed species tested. These results do not highest values below and above the first and third quartile, respectively, excluding outliers. Circles represent outliers that are between 1.5 and 3.0 times the interquartile range. $\mathrm{Cj}, \mathrm{C}$. japonica; $\mathrm{Ct}$, $\mathrm{C}$. trilobus; Ns, N. sericea; Ps, P. scandens; Rt, R. trichocarpa; Sc, S. china; Vd, V. dilatatum

support our overall hypothesis. Interestingly, most of our results do not support density-dependent seed predation process as predicted by the Janzen-Connell hypothesis (Janzen 1970, 1971; Connell 1971) and the predator 


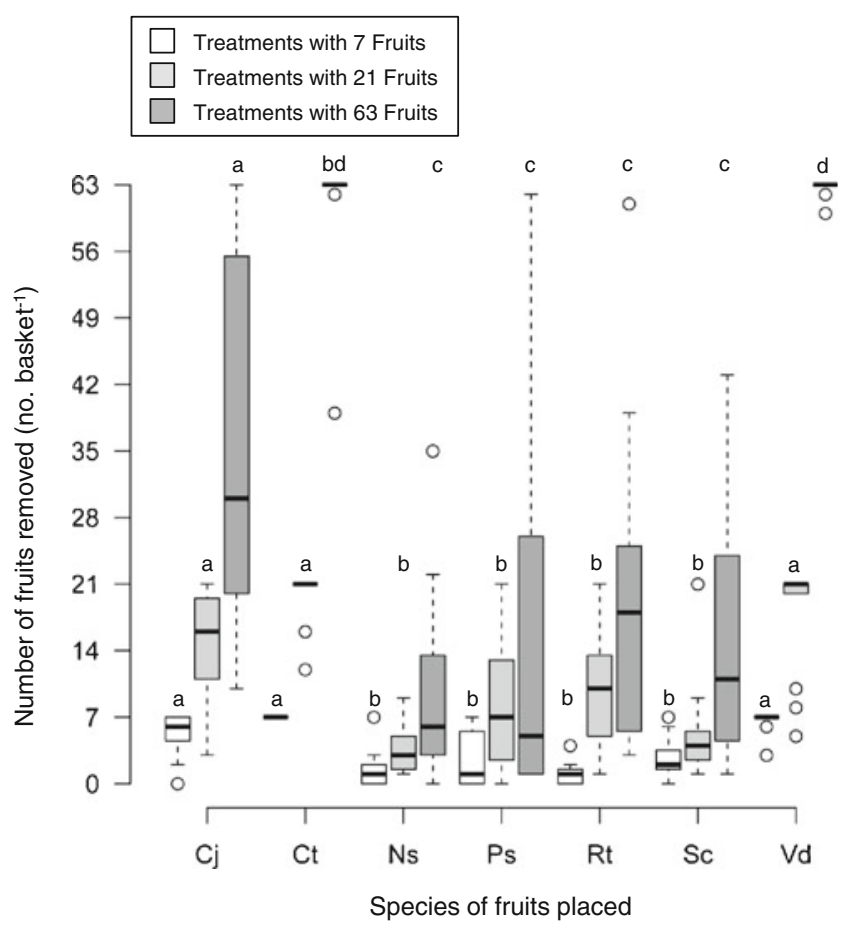

Fig. 3 The numbers of fruits removed in the treatments with fruits. Different letters in the same fruit-density treatments show significant differences among fruit-species treatments $(P<0.05$, Tukey's HSD test). See Fig. 2 for an explanation of the statistics indicated by the boxplots. Abbreviations of fruit species names are the same as in Fig. 2

satiation hypothesis (Janzen 1971; Burkey 1994). One possible explanation of these results would be that density dependence of seed predation depended on the spatial scale of observation in 1-ha study plot and that large scales than that addressed in the experiment would be more relevant. Another possible explanation would be that high density of fruiting plants and normal density of wood mice observed in the study plot hindered heavy density-dependent seed predation. The densities of the two wood mice species, $A$. speciosus and $A$. argenteus, in our study plot were thought to be normal based on comparison with densities at other study sites such as natural and planted forests in Japan (Miguchi 1996; Saitoh et al. 1999). Mice densities in a given area can vary tenfold (Miguchi 1996; Saitoh et al. 1999), so density-dependent seed predation may be frequently observed at certain times of the year. On the other hand, we observed that the presence or absence of neighboring fruits had small effects on seed removal for only S. china of the seven seed species tested. These results suggest that predation of bird-dispersed seeds by wood mice is reduced by the presence of fallen fruits of some species, such as $C$. trilobus and $V$. dilatatum, in close proximity to the seeds. In this case, naturally fallen fruits appear to have a risk-dilution effect on post-dispersal seed predation by wood mice, supporting our hypothesis. In addition, because fruit was
Table 3 The relationships between the mean number of removed seeds per species and the mean number of fruits removed across the seven fruit-species treatments

\begin{tabular}{llr}
\hline Fruit density & Seed species & Pearson's $r$ \\
\hline 7 fruits & Callicarpa japonica & $0.407 \mathrm{~ns}$ \\
& Cocculus trilobus & $-0.118 \mathrm{~ns}$ \\
& Neolitsea sericea & $0.317 \mathrm{~ns}$ \\
& Paederia scandens & $0.618 \mathrm{~ns}$ \\
& Rhus trichocarpa & $0.126 \mathrm{~ns}$ \\
& Smilax china & $0.036 \mathrm{~ns}$ \\
& Viburnum dilatatum & $0.410 \mathrm{~ns}$ \\
& Callicarpa japonica & $-0.008 \mathrm{~ns}$ \\
& Cocculus trilobus & $-0.210 \mathrm{~ns}$ \\
& Neolitsea sericea & $-0.774 *$ \\
& Paederia scandens & $-0.402 \mathrm{~ns}$ \\
& Rhus trichocarpa & $-0.650 \mathrm{~ns}$ \\
& Smilax china & $-0.427 \mathrm{~ns}$ \\
& Viburnum dilatatum & $-0.473 \mathrm{~ns}$ \\
& Callicarpa japonica & $-0.046 \mathrm{~ns}$ \\
& Cocculus trilobus & $-0.591 \mathrm{~ns}$ \\
& Neolitsea sericea & $-0.878^{* *}$ \\
& Paederia scandens & $-0.430 \mathrm{~ns}$ \\
& Rhus trichocarpa & $-0.908^{* *}$ \\
Smilax china & $-0.951^{* *}$ \\
& Viburnum dilatatum & $0.271 \mathrm{~ns}$ \\
\hline
\end{tabular}

$* P<0.05 ; * * P<0.01 ;$ ns $P \geq 0.05$ (significance levels)

removed by wood mice, fruit densities in the baskets gradually decreased over the study period. This would reduce density-dependent effects, but such situations would also occur naturally in the field.

Our experiment also showed that for seeds of $N$. sericea, $R$. trichocarpa, and S. china, the mean number of seeds removed significantly decreased with increasing mean number of fruits removed across the seven treatments using 21 fruits and/or 63 fruits, suggesting that wood mice consumption of fallen fruits affects survival of neighboring postdispersed seeds under conditions of high fruit density. These situations are similar to the pattern predicted by the predator satiation hypothesis, which states that low levels of seed predation are caused by predator satiation under and near fruiting plants in mast years (Janzen 1971; Burkey 1994). In contrast, the mean number of seeds removed and the mean number of fruits removed across the seven treatments were not correlated at most of densities of seven and 21 fruits per basket, suggesting that low densities of neighboring fruits may not sufficiently attract wood mice to reduce seed predation. Therefore, in our experiment, patterns similar to the predator satiation under strong densitydependent predation of both seeds and fruits (Janzen 1970, 

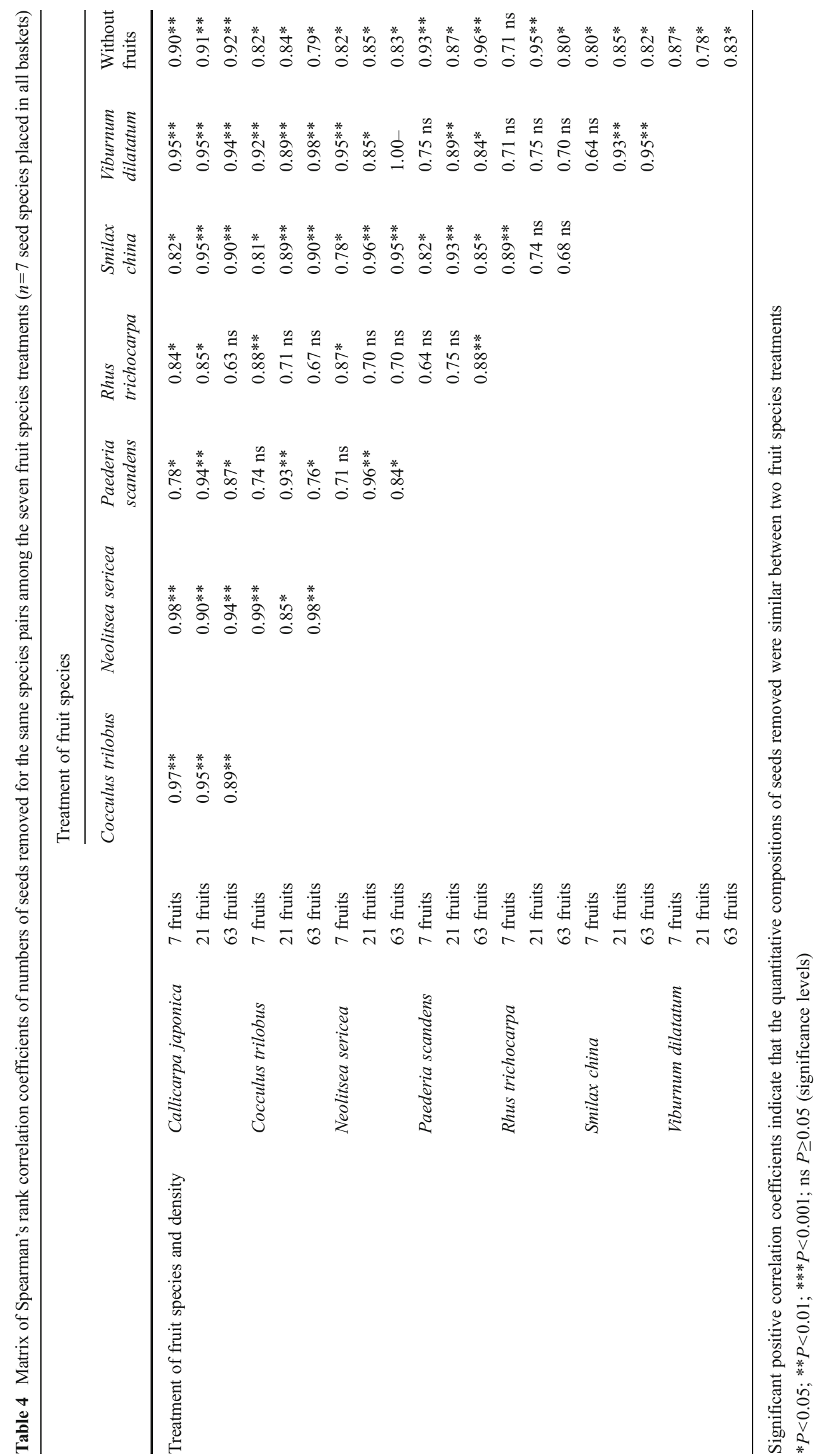
1971; Connell 1971) were observed for three (N. sericea, $R$. trichocarpa, and $S$. china) of seven seed species placed in high-fruit-density treatments.

Our experiment was performed in winter, when seeds and fruits suffer heavy predation by wood mice. Although we did not evaluate the effect of wood mice seed/fruit predation in autumn, the effect would be lower than that in winter because the food sources of wood mice in autumn are not only seeds but also invertebrates (mainly insects) (Ota et al. 1977). In contrast, the effect of ants in temperate region would be higher in the early autumn, when ants are more active than in the winter (Kollmann et al. 1998). Because the field experiment was performed in a good mast year for the tested plant species and the high-fruit-density treatments were realistic maximum levels, it appears that large fruit falls can satiate wood mice. In a poor or average mast year, the amount of fallen fruit may reduce density-dependent predation. On the other hand, litter accumulation hides fallen fruits and bird-dispersed seeds from wood mice and reduces their predation pressure (Price and Jenkins 1986; Schupp 1988). Thus, we may have overestimated natural seed/fruit predation in our experiment. Moreover, real densities of seeds arriving beneath fruiting plants affect postdispersal seed predation (Price and Jenkins 1986; Schupp 1988). Therefore, the results of our experiment may differ somewhat from natural patterns of seed/fruit predation. Future studies should investigate the forest-wide effects of fruiting plant density, fallen fruit density, bird-dispersed seed density, wood mouse density, and litter on the intensity of seed/fruit predation.

We also showed that fruit-species identity of neighboring fruits had no significant effects on seed removal for five of the seven seed species tested. However, for seeds of $P$. scandens and $R$. trichocarpa, seed removal was significantly smaller in $R$. trichocarpa fruit treatments than C. trilobus and/or $N$. sericea fruit treatments. In particular, seed removal of $R$. trichocarpa was lower in treatments with conspecific fruits than in those with heterospecific fruits, conflicting with the Janzen-Connell escape hypothesis. Species-dependent fruit predation may have been the result of the preference of wood mice for certain fruits. C. japonica, C. trilobus, and $V$. dilatatum fruits, which experienced high removal rates, appeared to be preferred by wood mice, whose preferences are affected by the size, nutritional value, and handling time of seeds/fruits (Wilson and Whelan 1990; Steele et al. 1996; Kollmann et al. 1998; Shimada 2001). Our experiment also demonstrated that the quantitative composition of seeds removed by wood mice was similar among the seven fruit-species treatments, suggesting that fruitspecies identity of neighboring fruits had practically no effect on the relative rank of wood mice preference for seeds of the seven species. As wood mice are primarily seed eaters, not fruit-pulp consumers, neighboring fruits would have little effect on which seeds are disturbed by wood mice. On the other hand, in the cafeteria experiment, which reproduced real patterns of bird-dispersed seeds and naturally fallen fruits, seeds of the seven species and fruits of a particular species were placed together in a basket. Thus, observed seed removal would actually reflect not only the effects of neighboring fruit density but also those of the rank of wood mice preference for seed species. However, in our cafeteria experiment, designed to evaluate the effects of fallen fruits on predation of post-dispersed seed communities, we observed constant preferences of wood mice across different densities and species of neighboring fruits.

Consequently, most of the results in this study do not support our overall hypothesis that heavy predation of fallen fruits under fruiting plants with high fallen fruit density would reduce the predation of neighboring post-dispersed seeds. However, a part of the results supported our hypothesis, suggesting that seed removal is affected by density and fruitspecies identity of neighboring fruits through complex interactions between the preference of wood mice for fruits and fruiting environment affecting their fruit preference. This also suggest that the complex interactions may play a key role in the survival of bird-dispersed seeds during the early postdispersal phase, and in turn, this process may contribute to the formation and persistence of a heterogeneous soil seed bank. This approach may contribute to understand the spatial patterns of fleshy-fruited plant recruitment.

Acknowledgments We thank Dr. Youichiro Takanose, Dr. Nobumasa Arai, Mr. Keinosuke Sanno, Mr. Yasuo Sugimoto, Mr. Masato Kamisako, Ms. Atsuko Endo, and Ms. Kanako Takahashi of Niigata University for their help with fieldwork and/or valuable discussions.

Funding This work was supported by MEXT KAKENHI (14560118 and 15310162).

\section{References}

Alcántara JM, Rey PJ, Sánchez-Lafuente AM, Valera F (2000) Early effects of rodent post-dispersal seed predation on the outcome of the plant-seed disperser interaction. Oikos 88:362-370

Burkey TV (1994) Toropical tree species diversity: a test of the Janzen-Connell model. Oecologia 97:533-540

Connell JH (1971) On the role of natural enemies in preventing competitive exclusion in some marine animals and in rain forest trees. In: der Boer PJ, Gradwell GR (eds) Dynamics of populations. Proceedings of the advanced study institute on dynamics of numbers in populations, Oosterbeek, 1970. Centre for Agriculture Publishing and Documentation, Wageningen, pp 298-310

Den Ouden J, Jansen PA, Smit R (2005) Jays, mice and oaks: predation and dispersal of Quercus robur and Q. petraea in north-western Europe. In: Forget PM, Lambert JE, Hulme PE, Vander Wall SB (eds) Seed fate. CAB International, Oxfordshire, pp 223-239

Hayashida M (1989) Seed dispersal by red squirrels and subsequent establishment of Korean pine. For Ecol Manag 28:115-129 
Herrera CM, Jordano P, López-Soria L, Amat JA (1994) Recruitment of a mast-fruiting, bird-dispersed tree: bridging frugivore activity and seedling establishment. Ecol Monogr 64:315-344

Higuchi H (1977) Stored nuts Castanopsis cuspidata as a food resource of nestling varied tits Parus varius. Tori 26:9-12

Holl KD (2002) Effects of shrubs on tree seedling establishment in an abandoned tropical pasture. J Ecol 90:179-187

Howe HF, Schupp EW, Westley LC (1985) Early consequences of seed dispersal for a Neotropical tree (Virola surinamensis). Ecology 66:781-791

Izhaki I, Walton PB, Safriel UN (1991) Seed shadows generated by frugivorous birds in an eastern Mediterranean scrub. J Ecol 79:575590

Janzen DH (1970) Herbivores and the number of tree species in tropical forests. Am Nat 104:501-528

Janzen DH (1971) Seed predation by animals. Annu Rev Ecol Syst 2:465-492

Kikuzawa K (1988) Dispersal of Quercus mongolica acorns in a broadleaved deciduous forest. 1. Disappearance. For Ecol Manag 25:1-8

Koike S, Morimoto H, Goto Y, Kozakai C, Yamazaki K (2008) Frugivory of carnivores and seed dispersal of fleshy fruits in cool-temperate deciduous forests. J For Res 13:215-222

Kollmann J, Coomes DA, White SM (1998) Consistencies in postdispersal seed predation of temperate fleshy-fruited species among seasons, years and sites. Funct Ecol 12:683-690

Kominami Y (1987) Removal of Viburnum dilatatum fruit by avian frugivores. Ecol Rev 21:101-106

Masaki T, Kominami Y, Nakashizuka T (1994) Spatial and seasonal patterns of seed dissemination of Cornus controversa in a temperate forest. Ecology 75:1903-1910

McClanahan TR, Wolfe RW (1987) Dispersal of ornithochorous seeds from forest edges in central Florida. Vegetatio 71:107-112

Miguchi H (1996) Dynamics of beech forest from the view point of rodents ecology: ecological interactions of the regeneration characteristics of Fagus crenata and rodents. Jpn J Ecol 46:185-189 (in Japanese)

Murray KG (1988) Avian seed dispersal of three Neotropical gapdependent plants. Ecol Monogr 58:271-298

Nathan R, Casagrandi R (2004) A simple mechanistic model of seed dispersal, seed predation and plant establishment: Janzen-Connell and beyond. J Ecol 92:733-746

Noma N, Yumoto T (1997) Fruiting phenology of animal-dispersed plants in response to winter migration of frugivores in a warm temperate forest on Yakushima Island, Japan. Ecol Res 12:119-129

Notman E, Gorchov DL, Cornejo F (1996) Effect of distance, aggregation, and habitat on levels of seed predation for two mammal-dispersed Neotropical rain forest tree species. Oecologia 106:221-227
Ota K, Abe H, Kobayashi T, Hujimaki Y, Higuchi S, Igarashi S, Kuwahara T, Maeda M, Ueda M, Takayasu T (1977) A synecological study of murid rodents (in Japanese with English summary). Res Bull Coll Exper Hokkaido Univ 34:119-159

Price MV, Jenkins SH (1986) Rodents as seed consumers and dispersers. In: Murray DR (ed) Seed dispersal. Academic, New York, pp 191-236

R Development Core Team (2011) R: A language and environment for statistical computing. R Foundation for Statistical Computing, Vienna, Austria. http://www.R-project.org

Robinson GR, Handel S (1993) Forest restoration on a closed landfill: rapid addition of new species by bird dispersal. Conserv Biol 7:271-277

Russell SK, Schupp EW (1998) Effects of microhabitat patchiness on patterns of seed dispersal and seed predation of Cercocarpus ledifolius (Rosaceae). Oikos 81:434-443

Saitoh T, Bjørnstad ON, Stenseth NC (1999) Density dependence in voles and mice: a comparative study. Ecology 80:638-650

Schupp EW (1988) Factors affecting post-dispersed seed survival in a tropical forest. Oecologia 76:525-530

Schupp EW (1995) Seed-seedling conflicts, habitat choice, and patterns of plant recruitment. Am J Bot 82:399-409

Seber GAF (1982) The estimation of animal abundance and related parameters, 2nd edn. Griffin, London

Shimada T (2001) Hoarding behaviors of two wood mouse species: different preference for acorns of two Fagaceae species. Ecol Res $16: 127-133$

Slocum MG, Horvitz CC (2000) Seed arrival under different genera of trees in a Neotropical pasture. Plant Ecol 149:51-62

Steele MA, Hadj-Chikh LZ, Hazeltine J (1996) Caching and feeding decisions by Sciurus carolinensis: responses to weevil-infested acorns. J Mammal 77:305-314

Takahashi K, Kamitani T (2003) Colonization of fleshy-fruited plants beneath perch plant species that bear fleshy fruit. $\mathrm{J}$ For Res 8:171-179

Takahashi K, Kamitani T (2004) Factors affecting seed rain beneath fleshy-fruited plants. Plant Ecol 174:247-256

Takahashi K, Sato K, Washitani I (2007) Acorn dispersal and predation patterns of four tree species by wood mice in abandoned cut-over land. For Ecol Manag 250:187-195

Toh I, Gillespie M, Lamb D (1999) The role of isolated trees in facilitating tree seedling recruitment at a degraded sub-tropical rainforest site. Rest Ecol 7:288-297

Wilson MF, Whelan CJ (1990) Variation in postdispersal survival of vertebrate-dispersed seeds: effects of density, habitat, location, and species. Oikos 57:191-198 